\title{
THE EFFECTIVENESS OF ALCOHOL GEL AND OTHER HAND-CLEANSING AGENTS AGAINST IMPORTANT NOSOCOMIAL PATHOGENS
}

\author{
Silvio Evandro Daniel Hernandes ${ }^{1}$; Aline Cláudia de Mello²; Janete Jordão Sant'Ana ${ }^{3}$; \\ Vanessa Sarto Soares ${ }^{1}$; Valdir Cassiolato ${ }^{3}$; Lourdes Botelho Garcia² ${ }^{2}$ Celso Luíz Cardoso ${ }^{2 *}$
}

\begin{abstract}
${ }^{1}$ Departamento de Medicina, Universidade Estadual de Maringá, Maringá, PR, Brasil; ${ }^{2}$ Departamento de Análises Clínicas, Universidade Estadual de Maringá, Maringá, PR, Brasil; ${ }^{3}$ Departamento Enfermagem, Universidade Estadual de Maringá, Maringá, PR, Brasil.
\end{abstract}

Submitted: October 14, 2002; Returned to authors: May 13, 2003; Approved: May 20, 2004.

\begin{abstract}
We compared the effectiveness of alcohol gel with that of the traditional hand-cleansing agents in removing clinical strains of Acinetobacter baumannii, methicillin-resistant Staphylococcus aureus, Escherichia coli, Enterococcus faecalis, Pseudomonas aeruginosa, and Candida albicans from artificially contaminated hands. The fingertips of 6 volunteers were contaminated with approximately $10^{6}$ of microbial cells, and then were washed with: plain liquid soap, alcohol gel, $70 \%$ ethyl alcohol (by weight), $10 \%$ povidone-iodine liquid soap (PVP-I), and 4\% chlorhexidine gluconate detergent. The experiments were performed using a Latin square statistical design, with six 6 x 5 randomized blocks, and the results were estimated by ANOVA. The products reduced from $93.83 \%$ (plain liquid soap) to $100 \%$ (PVP-I) of the microbial population applied to the hands. In 4 of 6 test microorganisms analyzed, 10\% PVP-I, alcohol gel, 70\% ethyl alcohol, and 4\% chlorhexidine had significantly higher removal rates than plain liquid soap $(P<0.05)$. The results confirm the effectiveness of alcohol gel for hand hygiene and suggest that 10\% PVP-I, alcohol gel, 70\% ethyl alcohol, and 4\% chlorhexidine may be more effective than plain liquid soap for removing A. baumannii, E. coli, E. faecalis, and C. albicans strains from heavily contaminated hands.
\end{abstract}

Key words: alcohol gel, hand-cleansing agents, nosocomial pathogens

\section{INTRODUCTION}

Ethyl alcohol is recommended in hospital practice in Brazil for hygienic handwashing because of its effectiveness and low cost (8). The major disadvantage of alcohol for skin antisepsis is its drying effect (21). In recent years, some commercial preparations containing $60 \%$ to $70 \%$ ethanol or isopropyl alcohol with addition of emollients to minimize skin drying (alcohol gel) have appeared in foreign markets. The effectiveness and acceptance of these products have been confirmed by investigators outside Brazil $(20,28,36)$.

In the present study we compared the effectiveness of alcohol gel with that of the traditional hand-cleansing agents in removing clinical microbial strains of Acinetobacter baumannii, methicillin-resistant Staphylococcus aureus, Escherichia coli, Enterococcus faecalis, Pseudomonas aeruginosa, and Candida albicans from artificially contaminated hands of human volunteers.

\section{MATERIALS AND METHODS}

\section{Test organisms}

The following test organisms were used: A. baumannii (1st block), methicillin-resistant $S$. aureus (2nd block), E. coli (3rd block), E. faecalis (4th block), P. aeruginosa (5th block), and $C$. albicans (6th block). All the test organisms were isolated from

*Corresponding author. Mailing address: Laboratório de Microbiologia, Departamento de Análises Clínicas, Universidade Estadual de Maringá. Av. Colombo, 5790.87020-900, Maringá, PR, Brasil. Fax: (+5544) 2614490. E-mail: deres@maringa.com.br 
patients at the University Hospital, a 95-bed teaching hospital (Universidade Estadual de Maringá, Maringá, Paraná, Brazil), and were identified by routine tests performed at the hospital's microbiology laboratory $(19,27)$.

\section{Culture media}

The following culture media were used: (i) MacConkey agar to recover A. baumannii and E. coli; (ii) tryptic soy agar containing $4 \mu \mathrm{g} / \mathrm{mL}$ of oxacillin (Bristol-Myers-Squibb Brasil Ltda., Santo Amaro, state of São Paulo, Brazil) to recover methicillin-resistant S. aureus, E. faecalis, and P. aeruginosa; (iii) Sabouraud dextrose agar containing $50 \mu \mathrm{g} / \mathrm{mL}$ of chloramphenicol (Carlo Erba, Duque de Caxias, state of Rio de Janeiro, Brazil) to recover C. albicans. All these media were purchased from Difco (Difco Laboratories, Detroit, Michigan, USA).

\section{Volunteers}

The volunteers were six healthy adults, three males and three females, with no skin problems. Their ages ranged from 20 to 23 years. As a control, before and after each experiment the fingertips of the volunteers were sampled by the finger-streak technique (4), with culturing for the presence of each test microorganism.

\section{Hand-cleansing agents}

The following hand-cleansing agents were used: (i) plain liquid soap (Cera Ingleza Indústria e Comércio Ltda., Belo Horizonte, state of Minas Gerais, Brazil); (ii) alcohol gel - ethyl alcohol plus emollient (Geef Ltda., São Paulo, São Paulo, Brazil); (iii) $70 \%$ ethyl alcohol, prepared at the moment of use by mixing $70 \mathrm{~g}$ absolute ethyl alcohol (Merck S. A. Indústria Química, Rio de Janeiro, Rio de Janeiro, Brazil) and $30 \mathrm{~g}$ distilled water; (iv) $10 \%$ povidone-iodine detergent, containing $1 \%$ active iodine; (v) $4 \%$ chlorhexidine gluconate detergent, containing $4 \%$ isopropyl alcohol. The latter two hand-cleansing agents were purchased from Indústria Farmacêutica Glicolabor, Ribeirão Preto, São Paulo, Brazil.

\section{Preparation of microbial suspension}

Five colonies of the test organism from a 24-h tryptic soy agar (Difco) (blocks 1 to 5) or Sabouraud dextrose agar (Difco) (block 6) were aseptically transferred to $13 \times 100 \mathrm{~mm}$ tubes containing $3 \mathrm{~mL}$ of tryptic soy broth (Difco) (blocks 1 to 5) or Sabouraud dextrose broth (Difco) (block 6) and incubated for 18 to $24 \mathrm{~h}$ at $37^{\circ} \mathrm{C}$. Next, the broth culture was centrifuged twice and the microbial cells resuspended in an equal volume of sterile distilled water, to give a final inoculum of approximately $10^{8}$ colony-forming units (CFU). Viable counts of these microbial suspensions were performed by the drop-plate technique described by Miles et al. (25), modified as follows. Briefly, decimal serial dilutions of the microbial suspension were prepared, $0.2 \mathrm{~mL}$ being added to $1.8 \mathrm{~mL}$ of sterile saline solution.
Three $0.02 \mathrm{~mL}$ drops of each of the $10^{-4}$ to $10^{-7}$ dilutions were applied to each quadrant of $90 \times 15 \mathrm{~mm}$ disposable plastic Petri plates (Inlab - Interlab Distribuidora de Produtos Científicos S.A., São Paulo, São Paulo, Brazil) containing the corresponding culture medium. After drying of the inoculum, the plates were incubated at $37^{\circ} \mathrm{C}$, for $24 \mathrm{~h}$, and drops that showed between 6 and 60 colonies were selected for counting.

\section{Experimental design}

The experiments were performed using a Latin-square statistical design, with six 6 x 5 randomized blocks. Each block included six experiments. In each experiment all hand-cleansing agents were tested, and all volunteers used each hand-cleansing agent once. In each experiment a different volunteer, whose hands were contaminated but were not treated with the handcleansing agents, acted as a control $(3,24)$. An interval of 7 days between experiments was maintained to allow restoration of the normal level of skin flora. The study was approved by the "Permanent Committee of Ethics in Research Involving Human Beings" of the State University of Maringá, and all volunteers gave written informed consent.

\section{Artificial contamination of the hands}

To remove transient bacterial flora, volunteers washed their hands with $5 \mathrm{~mL}$ of plain liquid soap and water (social wash) and dried them thoroughly with sterile paper towels. Each volunteer received $0.02 \mathrm{~mL}$ of the microbial suspension on each of the four fingertips of the left hand, with the palm facing upward and the fingers outstretched; the inoculum was spread by rubbing together opposing fingertips for 40 seconds. The process was completed by drying the fingers in air, without rubbing, for another 80 seconds before sampling (3). In blocks 1 to 5 , the fingertips of the volunteers were contaminated with approximately $10^{6} \mathrm{CFU}$, and in block 6 with $10^{5} \mathrm{CFU}$. We defined fingers 1 to 4 as denoting the index, middle, ring, and little fingers, respectively.

\section{Treatment with hand-cleansing agents}

Five milliliters of $70 \%$ ethyl alcohol or $3 \mathrm{~mL}$ of alcohol gel was carefully poured into the cupped hands, which were rubbed palm to palm (50 to 60 times), including fingertips, for 30 seconds, and then dried in air for 30 seconds. Five milliliters of povidone-iodine, chlorhexidine, and liquid soap were applied and rubbed on for 30 seconds in the same way, but this time with the hands previously moistened in sterile distilled water. Next, the hands were rinsed with $350 \mathrm{~mL}$ of sterile distilled water for 15 seconds, and softly dried with two sterile paper towels for 15 seconds (3).

\section{Recovery and culture of test organism}

Each volunteer sampled his eight fingers by rubbing for 3 minutes against $10 \mathrm{~g}$ of sterile glass beads ( $3 \mathrm{~mm}$ in diameter), in 
short, flat-bottomed glass tubes $(30 \times 70 \mathrm{~mm}$ for the $1 \mathrm{st}, 2 \mathrm{nd}$, and 3rd fingers, and $30 \times 65 \mathrm{~mm}$ for the 4 th fingers), containing $5 \mathrm{~mL}$ of $0.1 \%$ sterile peptone water (Difco) containing the following neutralizers: $1 \%$ polysorbate 80 (Difco), $0.5 \%$ lecithin (Santista Alimentos S. A., Ponta Grossa, Paraná, Brazil), and 1\% sodium thiosulfate (Cinética Química Ltda., São Paulo, São Paulo, Brazil), to prevent carryover inhibition (22). Next, viable counting of these sampling fluids (dilutions $10^{0}$ to $10^{-4}$ ) was performed by the modified drop-plate technique of Miles et al. (25).

\section{Evaluation of effectiveness of hand-cleansing agents}

The percentage of the test organisms removed from contaminated fingertips was calculated using the formula: removal rate $(\%)=100 \times[1-($ treated/control $)]$. Kruskal-Wallis analysis of variance was used to compare the removal rates of each test organism between the treatments, using the program "Statistica for Windows - Release 6.0" (StatSoft, Inc., Tulsa, Oklahoma, 2001). A value of $P<.05$ was considered significant.

\section{Controls}

In each experiment, viable counts of inoculum were made on corresponding agar plates with and without neutralizers, to investigate a possible inhibitory activity of these neutralizer agents on the test organism. The counts were made by the modified drop-plate technique (25). Additionally, in each experiment, after sampling, the fluid obtained from the 1st finger (right hand) of each volunteer was tested for carryover of antiseptic. Tests for carryover were made by inoculating both tubes of sampling fluid and controls $(0.1 \%$ peptone water with neutralizers) with $0.5 \mathrm{~mL}$ of a $10^{-4}$ dilution of an overnight tryptic soy broth culture of Staphylococcus aureus American Type Culture Collection (ATCC) 6538 (blocks 1 and 3 to 6) or Escherichia coli ATCC 25922 (block 2). After 5 to $10 \mathrm{~min}$ of contact, two $0.02 \mathrm{~mL}$ drops of each $10^{0}$ to $10^{-3}$ dilution from this material were applied to the surface of plates containing tryptic soy agar and MacConkey agar (Difco), respectively. The plates were incubated for 24 to $48 \mathrm{~h}$ at $37^{\circ} \mathrm{C}$, and the numbers of colonies of $S$. aureus or E. coli control strains growing from the sampling and the control fluids were compared $(2,23)$.

\section{RESULTS}

The effectiveness of the hand-cleansing agents tested in blocks 1 to 6 is shown in Table and Figure. The hand-cleansing agents reduced from $93.83 \%$ (plain liquid soap) to $100 \%$ (10\% PVP-I liquid soap) of the microbial population applied to the hands. In 4 of 6 test microorganisms analyzed, $10 \%$ povidoneiodine liquid soap, alcohol gel, 70\% ethyl alcohol, and 4\% chlorhexidine detergent had significantly higher removal rates than plain liquid soap $(P<.05)$ (Fig. 1).

The neutralizing agents showed no inhibitory activity on test organisms. According to the control used in our study, there was no carryover inhibition in the recovery of the test organisms from fingertips after treatment with hand-cleansing agents.

\section{DISCUSSION}

Several studies on outbreaks of nosocomial infection have suggested or shown the dissemination of Acinetobacter baumannii $(1,10,12,13)$, methicillin-resistant Staphylococcus aureus $(5,7,26,35,39)$, Escherichia coli $(16,18)$, Enterococcus faecalis (33), Pseudomonas aeruginosa (40), and Candida albicans $(9,30)$ via contaminated hands of hospital personnel. However, we have found few reports (4) on the effectiveness of alcohol gel for removing these nosocomial opportunistic pathogens from contaminated hands.

In our study, we clearly demonstrated that alcohol gel was as effective as the traditional hand-cleansing agents 10\% PVP-I liquid soap, $70 \%$ ethyl alcohol, $4 \%$ chlorhexidine gluconate detergent, and plain liquid soap in removing clinical strains of A. baumannii, methicillin-resistant S. aureus, E. coli, E. faecalis, $P$. aeruginosa, and $C$. albicans from heavily contaminated hands of human volunteers. Our findings are in agreement with previous reports from investigators outside Brazil, who have demonstrated the effectiveness of the alcohol-based gels in hand antisepsis $(4,20,28,36,37)$.

To our knowledge, this was the first attempt in Brazil to compare the immediate effect of an alcohol hand gel with that of the traditional hand-cleansing agents, using artificially contaminated hands as the experimental model.

The test organisms in our study were chosen for two reasons. First, because they are important potential nosocomial pathogens that may cause serious infections in debilitated and severely ill patients in intensive care units (31). In most of these infections, hand or fomite transmission is implicated $(1,9,18,34,35,40)$. Second, in hospital practice, a handrub with alcohol-based agents is especially indicated in situations in which compliance with recommended handwashing procedures is hampered by the lack or scarcity of sinks, or by nursing work overload, or both $(29,37)$. This situation is often found in intensive care units in Brazilian hospitals (29).

In our study, the number of $E$. coli cells recovered from hands of the control volunteers was approximately $2 \log _{10}(99 \%)$ lower than the original inoculum. This is not surprising, considering that $E$. coli strains may survive poorly on the skin of hands (14). Even so, large populations of E. coli cells remained viable on the fingertips (12,000 CFU), and may therefore present a potential risk of infection in hospitals.

In contrast, the number of test microorganisms applied on the fingertips in blocks 1,2 , 4, and 5 (about $10^{6}$ cells), and in block 6 (about $10^{5}$ cells) remained almost unchanged during the 2-min drying period. Thus, the hands of hospital personnel heavily contaminated by these opportunistic microorganisms, 


\begin{tabular}{|c|c|c|c|c|c|}
\hline Control & Plain liquid soap & $\begin{array}{l}\text { 4\% Chlor- } \\
\text { hexidine }\end{array}$ & Alcohol gel & $\begin{array}{l}70 \% \text { Ethyl } \\
\text { alcohol }\end{array}$ & $10 \%$ PVP-I \\
\hline $\begin{array}{r}\Rightarrow \text { Order of eff } \\
\text { Acinetobact }\end{array}$ & $\begin{array}{l}\text { ness } \\
\text { imannii }\end{array}$ & & & & \\
\hline \multicolumn{6}{|c|}{$\begin{aligned} \Rightarrow & \text { Order of effectiveness } \\
& \text { Enterococcus faecalis }\end{aligned}$} \\
\hline \multicolumn{6}{|c|}{$\begin{array}{l}\Rightarrow \text { Order of effectiveness } \\
\quad \text { Candida albicans }\end{array}$} \\
\hline Control & $\begin{array}{l}\text { 4\% Chlor- } \\
\text { hexidine }\end{array}$ & Plain liquid soap & Alcohol gel & $\begin{array}{l}70 \% \text { Ethyl } \\
\text { alcohol }\end{array}$ & $10 \%$ PVP-I \\
\hline \multicolumn{6}{|c|}{$\begin{aligned} \Rightarrow & \text { Order of effectiveness } \\
& \text { Methicillin resistant Staphylococcus aureus }\end{aligned}$} \\
\hline Control & Plain liquid soap & $\begin{array}{l}\text { 4\% Chlor- } \\
\text { hexidine }\end{array}$ & $10 \%$ PVP-I & $\begin{array}{c}70 \% \text { Ethyl } \\
\text { alcohol }\end{array}$ & Alcohol gel \\
\hline \multicolumn{6}{|c|}{$\begin{aligned} \Rightarrow & \text { Order of effectiveness } \\
& \text { Escherichia coli }\end{aligned}$} \\
\hline Control & Plain liquid soap & $\begin{array}{l}4 \% \text { Chlor- } \\
\text { hexidine }\end{array}$ & 10\% PVP-I & Alcohol gel & $\begin{array}{l}70 \% \text { Ethyl } \\
\text { alcohol }\end{array}$ \\
\hline \multicolumn{6}{|c|}{$\begin{array}{l}\Rightarrow \text { Order of effectiveness } \\
\quad \text { Pseudomonas aeruginosa }\end{array}$} \\
\hline
\end{tabular}

Figure 1. Multiple comparisons (Kruskal-Wallis) of effectiveness of hand-cleansing agents for removing clinical microbial strains from contaminated hands.

*Not significant differences between treatments for hand-cleansing agents on the same solid horizontal line $(P>.05)$.

in the absence of an effective handwashing procedure, may constitute an important transmission route of infection.

In our study, $4 \%$ chlorhexidine gluconate detergent was as effective as plain liquid soap, but it was less effective than alcohol gel, 70\% ethyl alcohol, and 10\% PVP-I liquid soap, for removing methicillin-resistant $S$. aureus from contaminated hands. Other studies also have suggested that chlorhexidine- based hand-cleansing agents seem to have a limited immediate effect against methicillin-resistant $S$. aureus strains $(15,17)$, despite their well-recognized persistence on the skin and their excellent activity against gram-positive bacteria $(8,21,32)$.

On the other hand, Wade et al. (38) demonstrated that $4 \%$ chlorhexidine gluconate detergent was better than plain soap for removing nosocomial vancomycin-resistant Enterococcus 
Table. Effectiveness of hand-cleansing agents for removing clinical microbial strains from contaminated hands.

\begin{tabular}{|c|c|c|c|c|c|c|c|c|c|c|c|c|}
\hline \multirow[b]{3}{*}{$\begin{array}{l}\text { Hand-cleansing } \\
\text { agents }\end{array}$} & \multicolumn{2}{|c|}{ 1st Block } & \multicolumn{2}{|c|}{ 2nd Block } & \multicolumn{2}{|c|}{ 3rd Block } & \multicolumn{2}{|c|}{ 4th Block } & \multicolumn{2}{|c|}{ 5th Block } & \multicolumn{2}{|c|}{ 6th Block } \\
\hline & \multicolumn{2}{|c|}{$\begin{array}{c}\text { Acinetobacter } \\
\text { baumannii }\end{array}$} & \multicolumn{2}{|c|}{$\begin{array}{l}\text { Methicillin- } \\
\text { resistant } \\
\text { S. aureus }\end{array}$} & \multicolumn{2}{|c|}{ Escherichia coli } & \multicolumn{2}{|c|}{$\begin{array}{l}\text { Enterococcus } \\
\quad \text { faecalis }\end{array}$} & \multicolumn{2}{|c|}{$\begin{array}{c}\text { Pseudomonas } \\
\text { aeruginosa }\end{array}$} & \multicolumn{2}{|c|}{$\begin{array}{l}\text { Candida } \\
\text { albicans }\end{array}$} \\
\hline & $\begin{array}{l}\text { Viable } \\
\text { counts } \\
\text { CFU* }\end{array}$ & $\begin{array}{l}\text { Removal } \\
\text { rate }(\%)\end{array}$ & $\begin{array}{l}\text { Viable } \\
\text { counts } \\
\text { CFU* }\end{array}$ & $\begin{array}{l}\text { Removal } \\
\text { rate }(\%)\end{array}$ & $\begin{array}{l}\text { Viable } \\
\text { counts } \\
\text { CFU* }\end{array}$ & $\begin{array}{l}\text { Removal } \\
\text { rate (\%) }\end{array}$ & $\begin{array}{l}\text { Viable } \\
\text { counts } \\
\text { CFU* }\end{array}$ & $\begin{array}{l}\text { Removal } \\
\text { rate (\%) }\end{array}$ & $\begin{array}{l}\text { Viable } \\
\text { counts } \\
\text { CFU* }\end{array}$ & $\begin{array}{l}\text { Removal } \\
\text { rate }(\%)\end{array}$ & $\begin{array}{l}\text { Viable } \\
\text { counts } \\
\text { CFU* }\end{array}$ & $\begin{array}{l}\text { Removal } \\
\text { rate }(\%)\end{array}$ \\
\hline $\begin{array}{l}10 \% \text { Povidone- } \\
\text { iodine }\end{array}$ & $\begin{array}{c}260 \\
\pm 600\end{array}$ & 99.9910 & $\begin{array}{c}190 \\
\pm 330\end{array}$ & 99.9873 & $\begin{array}{c}300 \\
\pm 640\end{array}$ & 97.5000 & $\begin{array}{c}420 \\
\pm 440\end{array}$ & 99.9998 & $\begin{array}{c}260 \\
\pm 510\end{array}$ & 99.9998 & $\begin{array}{c}0 \\
\pm 0\end{array}$ & 100 \\
\hline $\begin{array}{l}70 \% \text { Ethyl } \\
\text { alcohol }\end{array}$ & $\begin{array}{c}390 \\
\pm 470\end{array}$ & 99.9865 & $\begin{array}{c}1800 \\
\pm 4300\end{array}$ & 99.9800 & $\begin{array}{c}180 \\
\pm 390\end{array}$ & 98.5000 & $\begin{array}{c}680 \\
\pm 1000\end{array}$ & 99.9997 & $\begin{array}{c}25 \\
\pm 52\end{array}$ & 99.9999 & $\begin{array}{c}69 \\
\pm 140\end{array}$ & 99.9997 \\
\hline Alcohol gel & $\begin{array}{c}300 \\
\pm 360\end{array}$ & 99.9896 & $\begin{array}{c}6000 \\
\pm 18,000\end{array}$ & 99.6000 & $\begin{array}{c}140 \\
\pm 250\end{array}$ & 98.8333 & $\begin{array}{c}1200 \\
\pm 1500\end{array}$ & 99.9995 & $\begin{array}{c}160 \\
\pm 250\end{array}$ & 99.9999 & $\begin{array}{c}160 \\
\pm 230\end{array}$ & 99.9993 \\
\hline $4 \%$ chlorhexidine & $\begin{array}{c}2200 \\
\pm 2000\end{array}$ & 99.9241 & $\begin{array}{r}73,000 \\
\pm 54,000\end{array}$ & 95.1333 & $\begin{array}{c}560 \\
\pm 780\end{array}$ & 95.3333 & $\begin{array}{c}8400 \\
\pm 8600\end{array}$ & 99.9968 & $\begin{array}{c}2600 \\
\pm 4300\end{array}$ & 99.9983 & $\begin{array}{c}560 \\
\pm 790\end{array}$ & 99.9977 \\
\hline Plain liquid soap & $\begin{array}{c}4800 \\
\pm 4700\end{array}$ & 99.8400 & $\begin{array}{c}61,000 \\
\pm 62,000\end{array}$ & 95.9400 & $\begin{array}{c}740 \\
\pm 500\end{array}$ & 93.8400 & $\begin{array}{c}45,000 \\
\pm 42,000\end{array}$ & 98.3400 & $\begin{array}{c}3200 \\
\pm 6900\end{array}$ & 99.8000 & $\begin{array}{c}1600 \\
\pm 1400\end{array}$ & 99.3600 \\
\hline Control $\dagger$ & $\begin{array}{r}2,90 \\
\pm 2,1\end{array}$ & $0,000 \ddagger$ & $\begin{array}{r}1,50 \\
\pm 70\end{array}$ & $0,000 \ddagger$ & & $2,000+$ & $\begin{array}{r}2,70 \\
\pm 1,4\end{array}$ & $000 \$$ & $\begin{array}{l}1,60 \\
\pm 1,\end{array}$ & $0,000 \ddagger$ & $\begin{array}{l}250 \\
\pm 87\end{array}$ & $000 \ddagger$ \\
\hline
\end{tabular}

* Mean and standard deviation of final counts (48 counts in triplicate), after treatment with hand-cleansing agents.

$\dagger$ Volunteers without treatment with hand-cleansing agents.

$\$$ Mean and standard deviation of initial counts (48 counts in triplicate), without treatment with hand-cleansing agents.

faecium from contaminated fingertips. In our study, chlorhexidine was also more effective than plain liquid soap in removing $E$. faecalis from heavily contaminated hands (Fig. 1). These different results on microbial activity of $4 \%$ chlorhexidine gluconate detergent could be in part attributed to significant differences in chlorhexidine formulations from different manufacturers $(6,21)$.

Earlier studies have shown that alcoholic solutions, including 60 to 95 per cent ethanol or iso- or n-propanol, are generally more effective in killing transient microorganisms on the hands than antiseptic detergents or plain soap $(3,4)$. Our results were consistent with these studies.

However, 10\% PVP-I liquid soap showed a pronounced immediate effect. It was the only hand-cleansing agent tested in our study that completely removed the C. albicans population artificially applied to the fingertips. Other studies also have demonstrated the efficacy of povidone-iodine against transient microbial hand flora $(2,4,23)$.

A variety of hand-cleansing agents, including soap, detergents, and antiseptics, is available in most hospitals. In Brazil, there is no standardized method for comparing the effectiveness of these products. For this reason, in the present study we used a procedure based on a method proposed by Ayliffe et al. (3) as a standard test for hygienic hand disinfection.

We used a neutralization technique (11) to prevent carryover inhibition. Polysorbate 80 plus lecithin and sodium thiosulfate were used to neutralize chlorhexidine and povidone-iodine, respectively $(3,4,24)$. The neutralizer agents were effective, and showed no inhibitory effect on the test organisms.

In summary, the results obtained in the present study confirmed the effectiveness of ethanol-containing hand gel as a hygienic handrub, and suggested that $10 \%$ povidone-iodine liquid soap, alcohol gel, 70\% ethyl alcohol, and 4\% chlorhexidine gluconate detergent may be more effective than plain liquid soap for removing Acinetobacter baumannii, Escherichia coli, Enterococcus faecalis, and Candida albicans strains from heavily contaminated hands.

\section{ACKNOWLEDGMENTS}

S.E.D.H. received a scholarship from PIBIC/CNPq-UEM. We thank Vera L. D. Siqueira and Terezinha I. E. Svidzinski for supplying and identifying the microorganisms used in this study. We also thank the volunteers for their cooperation in our study, and Dr. Janet W. Reid for revision of the English text. 


\section{RESUMO}

\section{Eficácia do álcool gel e outros agentes degermantes na remoção de importantes patógenos hospitalares aplicados artificialmente nas mãos}

Nós comparamos a eficácia do álcool gel com a dos tradicionais agentes degermantes preconizados para a lavagem das mãos na remoção de amostras clínicas de Acinetobacter baumannii, Staphylococcus aureus resistente a meticilina, Escherichia coli, Enterococcus faecalis, Pseudomonas aeruginosa e Candida albicans das mãos artificialmente contaminadas. As pontas dos dedos dos voluntários $(\mathrm{n}=6)$ foram contaminadas com aproximadamente $10^{6}$ de células/ microrganismo teste. A seguir, as mãos foram lavadas com sabonete líquido não medicamentoso, álcool gel, álcool etílico $70 \%$ (concentração por peso) e soluções anti-sépticas detergentes de polivinilpirrolidona-iodo a 10\% (PVP-I) e de gluconato de clorhexidina $4 \%$. Os experimentos foram realizados segundo um quadrado latino com seis blocos aleatorizados 6 x 5 . Os resultados foram estimados por ANOVA. Os produtos reduziram de 93,83\% (sabão líquido) a 100\% (PVP-I 10\%) a população microbiana aplicada nas mãos. Em 4 dos 6 microrganismos testes analisados, o PVP-I 10\%, o álcool gel, o álcool etílico 70\% e a clorhexidina 4\% mostraram uma taxa de remoção significantemente superior a do sabão líquido $(P<0,05)$. Os resultados confirmam a eficácia do álcool gel na higienização das mãos e sugerem que o PVP-I 10\%, o álcool gel, o álcool etílico $70 \%$ e a clorhexidina $4 \%$ podem ser os agentes mais eficazes do que o sabão líquido não medicamentoso na remoção de Acinetobacter baumannii, Escherichia coli, Enterococcus faecalis e Candida albicans das mãos altamente contaminadas.

Palavras-chave: álcool gel, lavagem de mãos, patógenos hospitalares

\section{REFERENCES}

1. Allen, K.D.; Green, H.T. Hospital outbreaks of multi-resistant Acinetobacter anitratus: an airborne mode of spread? J. Hosp. Infect., 9:110-119, 1987.

2. Ayliffe, G.A.J.; Babb, J.R.; Bridges, K.; Lilly, H.A.; Lowbury, E.J.L.; Wilkins, M.D. Comparison of two methods for assessing the removal of total organisms and pathogens from the skin. J. Hyg., 75: 259$272,1975$.

3. Ayliffe, G.A.J.; Babb, J.R.; Quoraishi, A.H. A test for hygienic hand disinfection. J. Clin. Pathol., 31: 923-928, 1978.

4. Ayliffe, G.A.G.; Babb, J.R.; Davies, J.G.; Lilly, H.A. Hand disinfection: a comparison of various agents in laboratory and ward studies. $J$. Hosp. Infect., 11: 226-243, 1988.

5. Ayliffe, G.A.G. The progressive intercontinental spread of methicillinresistant Staphylococcus aureus. Clin. Infect. Dis., 24(Suppl 1): S74S79, 1997.

6. Babb, J.R.; Davies, J.G.; Ayliffe, G.A.J. A test procedure for evaluating surgical hand disinfection. J. Hosp. Infect., 18(Suppl. B): 41-49, 1991.
7. Boyce, J.M. Methicillin-resistant Staphylococcus aureus in hospitals and long term care facilities: microbiology, epidemiology, and preventive measures. Infect. Control Hosp. Epidemiol., 13: 725737, 1992.

8. Brazil, Ministry of Health. Wash your hands: information for health professionals. Norms and Technical Manuals. Documentation Center, Ministry of Health, Brasília, 1989, 32p. (In Portuguese)

9. Burnie, J.P.; Odds, F.C.; Lee, W.; Webster, C.; Williams, J.D. Outbreak of systemic Candida albicans in intensive care unit caused by cross infection. Br. Med. J., 290: 746-758, 1985.

10. Buxton, A.E.; Anderson, R.L.; Werdegar, D.; Atlas, E. Nosocomial respiratory tract infection and colonization with A. calcoaceticus. Epidemiologic characteristics. Am. J. Med., 65: 507-512, 1978.

11. Crémieux, A.; Fleurette, J. Methods of testing disinfectants. In: Block, S. (ed.). Disinfection, Sterilization and Preservation, Lea \& Febiger, Philadelphia, 1989, p.918-945.

12. Getschell-White, S.I.; Donowitz, L.G.; Groschel, D.H.M. The inanimate environment of an intensive care unit as a potential source of nosocomial bacteria: evidence for long survival of Acinetobacter calcoaceticus. Infect. Control Hosp. Epidemiol., 10: 402-406, 1989.

13. Go, S.E.; Urban, C.; Burns, J.; Kreiswirth, B.; Eisner, W.; Mariano, N.; Mosinka-Snipas, K.; Rahal, J.J. Clinical and molecular epidemiology of acinetobacter infections sensitive only to polymyxin B and sulbactam. Lancet, 344: 1329-1332, 1994.

14. Gontijo Filho, P.P.; Stumpf, M.; Cardoso, C.L. Survival of Gramnegative and Gram-positive bacteria artificially applied on the hands. J. Clin. Microbiol., 21: 652-653, 1985.

15. Goroncy-Bermes, P.; Schouten, M.A.; Voss, A. In vitro activity of a nonmedicated handwash product, chlorhexidine, and an alcohol-based hand disinfectant against multiply resistant Gram-positive microorganisms. Infect .Control Hosp. Epidemiol., 22: 194-196, 2001.

16. Guenthner, S.H.; Hendley, J.O.; Wenzel, R.P. Gram-negative bacilli as nontransient flora on the hands of hospital personnel. J. Clin. Microbiol., 25: 488-490, 1987.

17. Kampf, G.; Jarosch, R.; Ruden, H. Limited effectiveness of chlorhexidine based hand disinfectants against methicillin-resistant Staphylococcus aureus (MRSA). J. Hosp. Infect., 38: 297-303, 1988.

18. Knittle, M.A.; Eitzman, D.V.; Baer, H. Role of hand contamination of personnel in the epidemiology of gram-negative nosocomial infections. J. Pediatr., 86: 433-437, 1975.

19. Larone, D.H. Medically important fungi. A guide to identification. $3^{\text {rd }}$ ed., ASM Press, Washington DC, 1995, 274p.

20. Larson, E.L.; Eke, P.I.; Laughon, B.E. Efficacy of alcohol-based hand rinses under frequent-use conditions. Antimicrob. Agents Chemother., 30: 542-544, 1986.

21. Larson, E. 1995. APIC guidelines for handwashing and hand antisepsis in health care settings. Am. J. Infect. Control., 23: 251-269, 1995.

22. Lilly, H.A.; Lowbury, J.L.Transient skin flora. Their removal by cleansing or disinfection in relation to their mode of deposition. $J$. Clin. Pathol., 31: 919-922, 1978.

23. Lilly, H.A.; Lowbury, E.J.L.; Wilkins, M.D. Detergents compared with each other and with antiseptics as skin "degerming" agents. $J$. Hyg., 82: 89-93, 1979.

24. Lowbury, E.J.L. Assessing the effectiveness of antimicrobial agents applied to living tissues. J. Pharm. Belg., 36: 298-302, 1981.

25. Miles, A.A.; Misra, S.S.; Irwin, J.O. The estimation of the bactericidal power of the blood. J. Hyg., 38: 732-749, 1938.

26. Mulligan, M.E.; Murray-Leisure, K.A.; Ribner, B.S.; Standiford, H.C.; John, J.F.; Kauffman, C.A.; Yu, V.L. Methicillin-resistant Staphylococcus aureus: A consensus review of the microbiology, pathogenesis, and epidemiology with implications for prevention and management. Am. J. Med., 94: 313-328, 1993.

27. Murray, P.R.; Baron, E.J.; Pfaller, M.A.; Tenover, F.C.; Yolken, R.H. Manual of clinical microbiology. $7^{\text {th }}$ ed., ASM Press, Washington DC, 1999, 1774p. 
28. Newman, J.L.; Seitz, J.C. Intermittent use of an antimicrobial hand gel for reducing soap-induced irritation of health care personnel. Am. J. Infect. Control., 18: 194-200, 1990.

29. Pannuti, C.S.; Grinbaum, R.S. An overview of nosocomial infection control in Brazil. Infect. Control Hosp. Epidemiol., 16: 170-174, 1995.

30. Phelps, M.; Ayliffe, G.A.J.; Babb, J.R. An outbreak of candidiasis in a special care baby unit: the use of a resistogram typing method. $J$. Hosp. Infect., 7: 13-20, 1986.

31. Pittet, D.; Harbarth, S.J. The intensive care unit. In: Bennett, J.V.; Brachman, P.S. (eds.), Hospital Infections. 4th ed., Lippincott-Raven, Philadelphia, 1998, p.381-402.

32. Reybrouck, G. Handwashing and hand disinfection. J. Hosp. Infect., 8: 5-23, 1986

33. Rhinehart, E.; Smith, N.E.; Wennersten, C.; Gorss, E.; Freeman, J.; Eliopoulos, G.M.; Moellering, R.C.; Goldmann, D.A. Rapid dissemination of $\beta$-lactamase-producing, aminoglycoside-resistant Enterococcus faecalis among patients and staff on an infant-toddler surgical ward. N. Eng. J. Med., 323: 1814-1818, 1990.

34. Salzman, T.C.; Clark, J.J.; Klemm, L. Hand contamination of personnel as a mechanism of cross-infection in nosocomial infections with antibiotic-resistant Escherichia coli and Klebsiella-Aerobacter. Antimicrob. Agents Chemother., 7: 97-100, 1967.
35. Thompson, R.L.; Cabezudo, I.; Wenzel, R.P. Epidemiology of nosocomial infections caused by methicillin-resistant Staphylococcus aureus. Ann. Intern. Med., 97: 309-317, 1982

36. Voss. A.; Widmer, A.F. No time for handwashing? Handwashing versus alcoholic rub: can we afford 100\% compliance? Infect. Control Hosp. Epidemiol., 18: 205-208, 1997.

37. Zaragoza, M.; Sallés, M.; Gomez, J.; Bayas, J.M.; Trilha, A. Handwashing with soap or alcoholic solutions? A randomized clinical trial of its effectiveness. Am. J. Infect. Control, 27: 258-261, 1999.

38. Wade, J.J.; Desai. N.; Casewell, M.W. Hygienic hand disinfection for the removal of epidemic vancomycin-resistant Enterococcus faecium and gentamicin-resistant Enterobacter cloacae. J. Hosp. Infect., 18 211-218, 1991

39. Wenzel, R.P.; Nettleman, M.D.; Jones, R.N.; Pfaller, M.A. Methicillinresistant Staphylococcus aureus: implications for the 1990s and effective control measures. Am. J. Med., 91(Suppl 3B): 221S-27S 1991.

40. Widmer, A.F.; Wenzel, R.P.; Trilla, A.; Bale, M.J.; Jones, R.N.; Doebbeling, B.N. Outbreak of Pseudomonas aeruginosa infections in a surgical intensive care unit: probable transmission via hands of a health care worker. Clin. Infect. Dis., 16: 372-376, 1993. 